\title{
RESPONS NAPHTHALEN ACETIC ACID DAN UNSUR MIKRO MIKOMBI SUPER TERHADAP CHERELLE WILT PADA TANAMAN KAKAO
}

\author{
RESPONSE NAPHTHALEN ACETIC ACID AND ELEMENTS OF SUPER MICRO MIKOMBI \\ CHERELLE WILT PLANT ON COCOA
}

\author{
Stanley A.F. Walingkas dan Meity Rantung*) \\ "Fakultas Pertanian UNSRAT Manado
}

\begin{abstract}
This study aims to determine the effect of plant growth regulators and micro elements to cherelle wilt in cacao plants as well as finding the right business in tackling cherelle wilt in cacao plants. The research was carried out in the garden village folk Eris Eris Minahasa district for 8 months from January to August 2009. Spraying micro-nutrient elements is necessary to reduce cherelle wilt because the various treatments for the first observation is not significantly different, but the observations into two to seven observations to indicate a significant difference between treatments (percentage cherelle wilt on treatment without nutrient elements higher than sprayed). While spraying the treatment factor of plant growth regulators (NAA) is not necessary because the first observation and the two had no significant effect on the percentage of cherelle wilt affected only the third observation and further observations to a fourth, fifth, sixth and seventh again no effect. So is the treatment for fruit length and diameter showed that administration of the micro nutrients necessary for sprayed with micro nutrients result $22.10 \mathrm{~cm}$ higher than that is not sprayed is $19.43 \mathrm{~cm}$. As for the diameter of the fruit is affected by plant growth regulators. Treatment is better than $200 \mathrm{ppm} 100 \mathrm{ppm}$ and $0 \mathrm{ppm}$ (control).
\end{abstract}

Keywords: NAA, cocoa, mikombi

\begin{abstract}
ABSTRAK
Penelitian ini bertujuan mengetahui pengaruh pemberian zat pengatur tumbuh dan unsur mikro terhadap cherelle wilt pada tanaman kakao serta menemukan usaha yang tepat dalam menanggulangi cherelle wilt pada tanaman kakao. Penelitian ini dilaksanakan di kebun rakyat Desa Eris Kecamatan Eris Kabupaten Minahasa selama 8 bulan sejak Januari - Agustus 2009. Penyemprotan unsur hara mikro perlu dilakukan untuk mengurangi cherelle wilt sebab pada berbagai perlakuan untuk pengamatan pertama tidak berbeda nyata namun pada pengamatan ke dua sampai pengamatan ke tujuh menunjukkan adanya perbedaan nyata antar perlakuan (prosentase cherelle wilt pada perlakuan tanpa unsure hara lebih tinggi dari yang disemprot). Sementara faktor penyemprotan dengan perlakuan zat pengatur tumbuh (NAA) tidak perlu dilakukan sebab pengamatan pertama dan ke dua tidak berpengaruh nyata pada persentase cherelle wilt hanya berpengaruh pada pengamatan ke tiga dan selanjutnya pengamatan ke empat, ke lima, ke enam dan ke tujuh kembali tidak berpengaruh. Begitu juga perlakuan untuk panjang dan diameter buah menunjukkan bahwa pemberian unsur hara mikro perlu dilakukan sebab yang disemprot dengan unsur hara mikro hasilnya $22,10 \mathrm{~cm}$ lebih tinggi dari yang tidak disemprot yaitu $19,43 \mathrm{~cm}$. Sementara untuk diameter buah dipengaruhi oleh zat pengatur tumbuh. Perlakuan 200 ppm lebih baik dari 100 ppm dan 0 ppm (kontrol).

Kata kunci : NAA, kakao, mikombi
\end{abstract}

Eugenia Volume 18 No. 2 Agustus 2012 


\section{PENDAHULUAN}

Tanaman kakao, bijinya mengandung alkaloid theobromin dan lemak berkisar antara 56$75 \%$ yang fungsinya sama dengan hidrat arang dan protein sebagai makanan cadangan dalam biji. Kandungan lemaknya tinggi sehingga bijinya dapat digunakan sebagai bahan dasar industri mentega. Biji kakao juga mengandung minyak eteris yang dapat memberi aroma khas bagi cokelat (Butarbutar, 1975).

Tercatat bahwa kebutuhan dunia akan biji kakao meningkat dari tahun ke tahun. Tahun 1984/1985 kebutuhan 1,848 ton/tahun, tahun 1990/1991 kebutuhan menjadi 2,288 ton/tahun. Produksi biji kakao Indonesia terus meningkat dari 33,170 ton, tahun 1986 menjadi 104,872 ton pada tahun 1990, begitu juga olahan 1,877 ton pada tahun 1986 menjadi 15,255 ton pada tahun 1990, peningkatan sebesar $54,5 \%$ dalam bentuk biji sedangkan $81,3 \%$ dalam bentuk olahan (Susanto, 1994).

Pemerintah telah memberikan perhatian yang cukup besar dalam usaha meningkatkan produksi biji kakao. hal ini terbukti dengan dilakukannya percepatan pengembangan budidaya kakao di beberapa perkebunan negara, perkebunan swasta maupun perkebunan rakyat. Seiring dengan pengembangan wilayah pertanaman hingga kini mencapai luar areal perkebunan di Indonesia 318.938 ha, dilakukan pula berbagai usaha untuk meningkatkan produktifitas, salah satunya dengan pemupukan dan pemakaian zat pengatur tumbuh.

Upaya untuk meningkatkan produksi, yang menarik pada tanaman kakao adalah adanya peristiwa cherelle wilt. Menurut Darjanto (1977) hasil kakao ditentukan oleh pembentukan buah dan jumlah buah yang mengalami kelayuan. Cherelle wilt (kelayuan buah muda) ini terjadi pada umur 2-3 bulan sejak perkembangannya (Alvim, 1977).

Kelayuan buah muda pada kakao mendapat perhatian karena dapat mempengaruhi produksi. kenyataan ini dapat dilihat bahwa dari buah yang terbentuk, hanya sebagian kecil yang dapat tumbuh terus menjadi buah dewasa yang dapat dipanen. Kehilangan hasil yang disebabkan cherelle wilt dapat mencapai lebih $80 \%$ dari buah yang terbentuk (Alvim, 1977; Butarbutar, 1975).

Lanjut dikatakan oleh Alvim (1977) dipandang dari segi fisiologi, terjadinya cherelle wilt adalah sama dengan peristiwa rontoknya buah pada kebanyakan pohon buah-buahan. Buah layu tersebut biasanya tidak rontok melainkan tetap bertahan di pohon. Penyebab utama terjadinya cherelle wilt belum diketahui secara pasti, namun berdasarkan penelitian yang dilakukan sejumlah peneliti di beberapa negara berpendapat bahwa faktor zat tumbuh dan ketersediaan zat makanan dapat berpengaruh pada kelayuan buah muda (Darjanto, 1977).

Penggunaan auksin buatan untuk mengurangi cherelle wilt telah banyak dilakukan dan ternyata memberikan efek yang baik. Naphthalena Acetic Acid (NAA) merupakan auksin sintetik yang sering digunakan dalam praktek. Hal ini disebabkan NAA lebih stabil kimianya dan mempunyai daya mobil yang rendah di dalam tanaman. Sifat-sifat ini mendukung keberhasilannya karena kemantapan dan pengaruhnya berlangsung lama (Zaenal, 1987).

Di beberapa negara telah dilakukan usaha mengurangi cherelle wilt dengan pemupukkan, pemupukkan dengan nitrogen fosfor dan kalium ternyata tidak mengurangi persentase cherelle wilt meskipun dapat meningkatkan hasil. Mengenai pengaruh unsur mikro belum diketahui secara pasti, tetapi melihat kenyataan ini diduga unsur mikro merupakan faktor pembatas yang berpengaruh pada cherelle wilt. Arti penting unsur hara mikro dapat dilihat pada peranan yang khas dari masingmasing unsur hara tersebut bagi pertumbuhan dan perkembangan tanaman (Buckman dan Brady, 1960; Epstain, 1972; Marscher, 1986; Mengel dan Kirkby, 1978).

Penggunaan zat pengatur tumbuh dan unsur mikro dalam mencegah layunya buah kakao muda masih kurang dilakukan, sehingga sampai seberapa jauh keberhasilannya dalam menghambat kelayuan buah muda belum banyak diketahui. Berdasarkan hal-hal di atas, maka dilakukan penelitian penggunaan zat pengatur tumbuh NAA dan unsur mikro mikombi super untuk mengurangi cherelle wilt pada tanaman kakao. 
Sehubungan dengan peningkatan produksi tanaman kakao maka masalah yang dihadapi adalah adanya peristiwa cherelle wilt (kelayuan buah muda) ini terjadi pada umur 2-3 bulan sejak perkembangannya, kelayuan buah muda pada buah kakao perlu mendapat perhatian karena dapat mempengaruhi produksi. Sebab hasil kakao ditentukan oleh pembentukan buah dan jumlah buah yang mengalami kelayuan. Kenyataan ini dapat dilihat bahwa dari buah yang terbentuk, hanya sebagian kecil yang dapat tumbuh terus menjadi buah dewasa yang dapat dipanen. Kehilangan hasil yang disebabkan cherelle wilt dapat mencapai $80 \%$ dari buah yang terbentuk. Dari segi fisiologi terjadinya cherelle wilt adalah sama dengan peristiwa rontoknya buah pada kebanyakan pohon buah-buahan. Buah layu tersebut biasanya tidak rontok melainkan tetap bertahan di pohon. Penyebab utama terjadinya cherelle wilt belum diketahui secara pasti. Namun berdasarkan penelitian yang dilakukan sejumlah peneliti di beberapa negara berpendapat bahwa faktor zat tumbuh dan ketersediaan zat makanan dapat berpengaruh pada kelayuan buah muda.

Penelitian ini bertujuan untuk mengetahui pengaruh pemberian zat pengatur tumbuh dan unsur mikro terhadap cherelle wilt pada tanaman kakao serta menemukan usaha yang tepat dalam menanggulangi cherelle wilt pada tanaman kakao.

\section{METODE PENELITIAN}

Penelitian dilaksanakan di kebun rakyat Desa Eris Kecamatan Eris Kabupaten Minahasa. Lama penelitian delapan bulan yaitu sejak bulan Januari-Agustus 2009.

Pada penelitian ini digunakan tanaman kakao yang telah berproduksi. Dalam hal ini diusahakan tanaman yang pertumbuhannya seragam. Zat pengatur tumbuh NAA yang berupa bubuk warna putih dan mikombi super berupa bubuk warna kecoklatan yang mengandung ( $\mathrm{Fe}$ 2,7\%; Mn 1,36\%; Zn 0,48\%; Cu 1,36\%; Mg 0,32\%; B 0,7\%; Co 0,15\% dan Mo 0,02\%).

\section{Pelaksanaan Penelitian Pembuatan Petak Percobaan}

Dibuat tiga blok yang masing-masing mencakup semua kombinasi perlakuan yang diujukan. Setiap kombinasi perlakuan terdiri dari dua pohon.

\section{Pemilihan Bahan Tanaman}

Pemilihan bahan tanaman didasarkan pada umur dan kondisi pertumbuhan yang relatif sama, dengan mengukur diameter batangnya.

\section{Pemberian Tanda pada Buah}

Populasi dibagi dalam beberapa kelompok (batang pokok, cabang primer dan cabang sekunder). Anggota sampel ditarik dari setiap kelompok (strata). Buah muda yang dipilih berukuran panjang $2-5 \mathrm{~cm}$ kemudian ditandai dengan benang.

\section{Pemberian Perlakuan}

Pemberian NAA dilakukan dengan penyemprotan langsung pada semua buah. Penyemprotan dilakukan tiga kali dengan selang waktu tiga minggu. Penyemprotan mikombi super diarahkan ke smua tajuk daun. Penyemprotan dilakukan dua kali, penyemprotan pertama dilakukan bersamaan dengan penyemprotan NAA yang pertama.

\section{Varibel Pengamatan}

Jumlah cherelle wilt dihitung satu minggu setelah perlakuan. Pengamatan dilakukan dengan interval waktu satu minggu selama 14 kali pengamatan. Cherelle wilt yang telah dihitung segera dilepas dari pohon agar tidak menyulitkan perhitungan berikutnya. Buah yang layu karena terserang patogen dihitung dan segera lepas dari pohon.

Ukuran buah ditentukan dengan mengukur panjang dan tebal buah dengan memakai jangka sorong. Panjang buah diukur dari pangkal sampai ujung, sedangkan tebalnya diukur pada bagian tengah buah. 


\section{Rancangan Percobaan}

Percobaan ini menggunakan rancangan pola faktorial 3×2 dalam rancangan acak kelompok (RAK) dengan dua faktor perlakuan kombinasi yang diulang sebanyak tiga kali, dengan setiap unit perlakuan menggunakan dua pohon, sehingga jumlah tanaman yang digunakan adalah 36 pohon. Adapun faktor perlakuan yang dimaksud perlakuan kombinasi antara zat pengatur tumbuh NAA (N) dengan unsur mikro $(P)$.

Faktor pertama zat pengatur tumbuh $(\mathrm{N})$ dengan tiga taraf yaitu :

$\mathrm{N} 1=0 \mathrm{ppm}$

$\mathrm{N} 2=100 \mathrm{ppm}$

$\mathrm{N} 3=200 \mathrm{ppm}$

Faktor kedua adalah unsur mikro $(\mathrm{P})$ dengan dua taraf yaitu:

$\mathrm{P} 1=$ tanpa unsur mikro

$\mathrm{P} 2$ = unsur mikro

\section{HASIL DAN PEMBAHASAN}

Pengamatan yang dilakukan terhadap jumlah cherelle wilt setelah tanaman kakao diberikan zat pengatur tumbuh Naphthalen Acetic Acid (NAA) dan pupuk mikro sesuai dengan perlakuan dimaksudkan untuk melihat sejauh mana pengaruhnya terhadap pertumbuhan dari bunga kakao, bunga kering sampai menjadi buah kakao. Hasil pengamatan terhadap cherelle wilt pada berbagai pengamatan disajikan pada Tabel 1 .

Hasil rata-rata persentase jumlah cherelle wilt dari beberapa kali pengamatan pada Tabel 1 menunjukkan bahwa makin lama pertumbuhan dan perkembangan bunga kakao memperlihatkan adanya penurunan, ini artinya jumlah buah yang gugur makin lama makin berkurang dari berbagai perlakuan. Akan tetapi hasil analisa statistik (sidik ragam) menunjukkan interaksi antar perlakuan zat pengatur tumbuh dan unsur hara mikro pada tanaman kakao dari pengamatan pertama sampai pengamatan ketujuh tidak menunjukkan perbedaan yang nyata. Hal ini mungkin disebabkan karena penggunaan zat pengatur tumbuh dan unsur mikro yang terlalu kurang ataupun pada saat pengamatan pengaruhnya belum nampak. Hal tersebut di atas apabila melihat angka pada pengamatan ke tujuh untuk perlakuan N1P1 (kontrol) persentase jumlah cherelle wilt lebih tinggi (9,97\%) dari jumlah persentase perlakuan yang diberikan zat pengatur tumbuh dan unsur mikro, walaupun pengaruhnya tidak nyata setelah tanaman kakao diperlakukan dengan penyemprotan zat pengatur tumbuh dan unsur hara mikro, tapi buah yang mengering (cherelle wilt) makin berkurang.

Analisa sidik ragam pada Tabel 2 menunjukkan bahwa penyemprotan unsur hara mikro untuk berbagai perlakuan pada pengamatan pertama tidak berbeda nyata antar perlakuan namun pada pengamatan kedua sampai pengamatan ketujuh menunjukkan adanya perbedaan nyata antar perlakuan. Dengan melihat hasil pengaruh unsur hara mikro terhadap persentase cherelle wilt. Pada pengamatan pertama pengaruhnya belum nampak tapi pada pengamatan kedua hingga pengamatan terakhir yaitu pengamatan ketujuh menunjukkan perbedaan yang nyata antar perlakuan.

Perlakuan yang tidak disemprot persentase cherelle wilt lebih tinggi dari pada perlakuan yang disemprot yang persentasenya lebih rendah dari pengamatan kedua hingga ketujuh. Ini artinya apabila diberikan unsur hara mikro pada tanaman kakao prosentase cherelle wilt akan berkurang. Berkurangnya cherelle wilt dikatakan oleh Darjanto (1977) pemupukan dengan unsur hara makro saja sering kurang cukup karena terdapat sejumlah unsur hara lainnya yang dibutuhkan oleh tanaman. Unsur hara yang dimaksud tergolong unsur hara mikro seperti seng, mangan, boron, besi, tembaga dan lain-lain, yang secara langsung memberikan pengaruh dengan fungsi-fungsi yang berbeda-beda sesuai dengan unsur masing-masing. Mengenai pengaruh unsur mikro terhadap cherelle wilt beberapa penelitian yang pernah dilakukan ternyata menunjukkan hasil yang positif.

Sementara faktor penyemprotan dengan perlakuan zat pengatur tumbuh (NAA) pengamatan pertama dan kedua tidak berpengaruh nyata pada prosentase cherelle wilt hanya berpengaruh pada pengamatan ketiga dan selanjutnya pengamatan keempat, kelima, keenam dan ketujuh kembali tidak berpengaruh. 
Tabel 1. Rata-rata Jumlah Cherelle Wilt (\%) pada Berbagai Perlakuan (minggu)

(Table 1. Average Number Cherelle Wilt (\%) in various treatment (weeks))

\begin{tabular}{cccccccc}
\hline Perlakuan & 1 & 2 & 3 & 4 & 5 & 6 & 7 \\
\hline N1P1 & 31,80 & 24,67 & 18,55 & 17,97 & 15,33 & 16,07 & 9,97 \\
N1P2 & 28,33 & 21,53 & 16,20 & 15,33 & 14,50 & 14,60 & 8,50 \\
N2P1 & 26,67 & 25,27 & 17,18 & 17,53 & 15,93 & 15,20 & 8,77 \\
N2P2 & 26,40 & 20,83 & 14,87 & 15,33 & 12,33 & 13,27 & 7,72 \\
N3P1 & 24,83 & 23,67 & 17,28 & 16,87 & 15,53 & 15,60 & 7,70 \\
N3P2 & 22,83 & 20,07 & 13,57 & 14,33 & 12,67 & 13,80 & 6,60 \\
\hline
\end{tabular}

Tabel 2. Pengaruh Penyemprotan Unsur Hara Mikro Terhadap Jumlah Rata-rata Cherelle Wilt (CW) dan Panjang Buah Kakako pada Pengamatan Pertama Hingga Pengamatan Ketujuh (minggu)

(Table 2. Effect of Spraying Micro Nutrients to Total Average Cherelle Wilt (CW) and length of fruit Kakako Until First Observations Observations on seven (weeks))

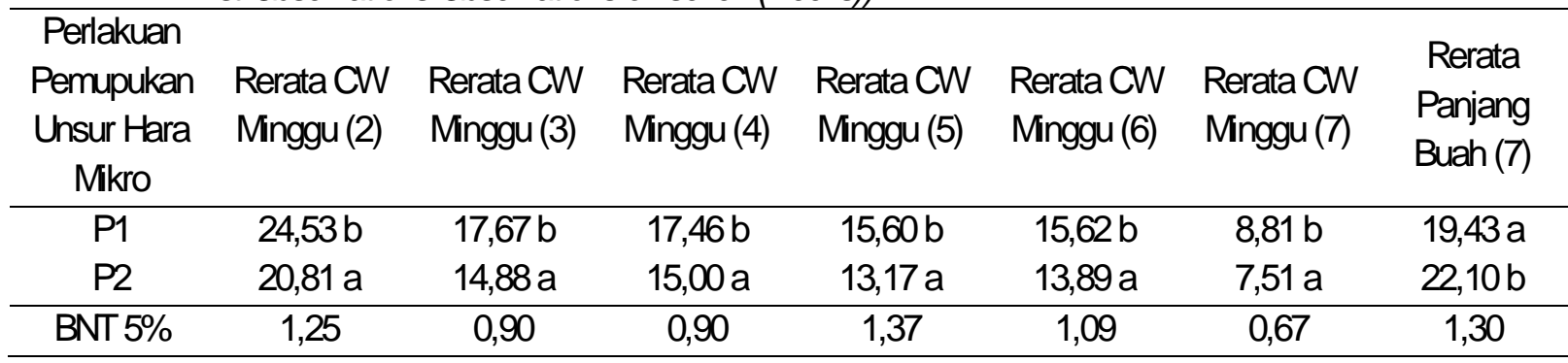

$\mathrm{CW}=$ Cherelle Wilt

2,3,4,5,6,7 = minggu ke

Tabel 3. Pengaruh Perlakuan Zat Pengatur Tumbuh (NAA) terhadap Jumlah Rata-rata Cherelle Wilt dan Diameter Buah Kakao pada Beberapa Pengamatan (minggu)

(Table 3. Treatment Effect of plant growth regulators (NAA) to the number average diameter Cherelle Wilt and Cocoa Fruits in Some Observations (weeks))

\begin{tabular}{cccc}
\hline $\begin{array}{c}\text { Perlakuan Zat Pengatur } \\
\text { Tumbuh (NAA) }\end{array}$ & $\begin{array}{c}\text { Rerata Cherelle Wilt } \\
\text { Minggu 3 }\end{array}$ & $\begin{array}{c}\text { Rerata Cherelle Wilt } \\
\text { Minggu 7 }\end{array}$ & $\begin{array}{c}\text { Rerata Diameter Buah } \\
\text { Minggu 7 }\end{array}$ \\
\hline N1 & $17,38 \mathrm{~b}$ & $9,24 \mathrm{c}$ & $7,5 \mathrm{a}$ \\
N2 & $16,03 \mathrm{a}$ & $8,25 \mathrm{~b}$ & $7,7 \mathrm{a}$ \\
N3 & $15,43 \mathrm{a}$ & $7,00 \mathrm{a}$ & $9,08 \mathrm{~b}$ \\
\hline BNT 5\% & 1,10 & 0,82 & 1,03
\end{tabular}

Pengaruhnya zat pengatur tumbuh (NAA) pada pengamatan ketiga adalah adanya perbedaan antara perlakuan yang diberikan zat pengatur tumbuh yaitu $100 \mathrm{ppm}$ dan $200 \mathrm{ppm}$ dengan $0 \mathrm{ppm}$ (yang merupakan kontrol). Hal ini menunjukkan dengan pemberian zat pengatur tumbuh dapat menekan bertambahnya cherelle wilt pada tanaman kakao, dan pengaruhnya hanya sesaat, ini disebabkan karena daya kerja dari zat pengatur tumbuh sangat ditentukan oleh jumlah yang diberikan bisa sebagai pendorong pertumbuhan tapi bisa saja penghambat pertumbuhan. Ini terlihat bahwa zat pengatur tumbuh tidak dapat diektrasi dari buah muda yang menunjukkan gejala layu, indeks kelayuan buah kako muda dengan kandungan auksin dalam buah berkorelasi negatif, maksudnya gejala awal buah kakao layu muda berkaitan dengan rendahnya kandungan auksin dalam hal ini naphthalen acetic acid dalam buah. Sedangkan buah yang telah mencapai panjang 10 $\mathrm{cm}$ pada umur 90 hari sudah tidak akan mengering lagi karena produksi zat pengatur tumbuh alami oleh biji telah dapat menjamin pertumbuhan buah (Nihols, 1964 dalam Wood, 1975).

Pengamatan gangguan patogen per pohon yaitu buah yang layu karena diserang 
pathogen langsung segera dilepas dari pohon sementara ukuran buah jadi yang ditentukan dengan mengukur panjang dan tebal buah, dapat dilihat pada Tabel 2 dan Tabel 3. Perlakuan untuk panjang dan diameter buah menunjukkan bahwa pemberian unsur hara mikro perlu dilakukan sebab yang disemprot dengan unsur hara mikro hasilnya $22,10 \mathrm{~cm}$ lebih tinggi dari yang tidak disemprot yaitu $19,43 \mathrm{~cm}$. Sementara untuk diameter buah dipengaruhi oleh zat pengatur tumbuh. Perlakuan 200 ppm lebih baik dari 100 ppm dan 0 ppm (control). Ini disebabkan zat pengatur tumbuh berperan dalam pembagian hasil fotosintesis, pengisian biji dan merangsang pengangkutan senyawa organik ke buah yang sedang berkembang. Selain itu auksin juga berperan dalam mendorong diferensiasi floem dan xylem.

\section{KESIMPULAN DAN SARAN}

\section{Kesimpulan}

Cherelle wilt makin lama makin berkurang dari berbagai perlakuan, walaupun interaksi antar perlakuan tidak berbeda nyata dari pengamatan pertama hingga pengamatan terakhir.

Penyemprotan unsur hara mikro perlu dilakukan untuk mengurangi cherelle wilt dan memperpanjang buah kakao

Faktor penyemprotan dengan perlakuan zat pengatur tumbuh (NAA) tidak perlu dilakukan sebab pengamatan pertama dan kedua tidak berpengaruh nyata pada persentase cherelle wilt hanya berpengaruh pada pengamatan ketiga dan selanjutnya pengamatan keempat, kelima, keenam dan ketujuh kembali tidak berpengaruh. Begitu juga perlakuan untuk panjang buah tidak menunjukkan perbedaan yang nyata.

\section{Saran}

Perlu dilakukan penelitian lanjut dengan cara meningkatkan konsentrasi zat pengatur tumbuh Naphthalen Acetic Acid (NAA)

\section{DAFTAR PUSTAKA}

Alvim, P de T. 1977. Cacao dalam Paulo de T Alvin and T.T. Kozlowski (ed). Ecophysiologi of
Tropical Crops. Academic Press. New York. p. 279-313.

Bidwael, R.G.S. 1979. Plant Phyysiology. Mac. Millan Publishing. Co Inc. New York $p$. 643.

Buckman, H.O. and H.C. Brady. 1960. The Nature and Properties of Soils (sixth edition) Mc.Millan Co New York 567 p.

Butarbutar, 1975. Prinsip-prinsip Pemeliharaan Tanaman Coklat Bulk. PT. Perkebunan IV $35 \mathrm{~h}$.

Danoesastro, H. 1978. Zat Pengatur Tumbuhan Dalam Pertanian. Penerbit Yayasan Pembina Fakultas Pertanian Universitas Gadjah Mada Yogyakarta. $115 \mathrm{~h}$.

Darjanto. 1977. Beberapa Catatan Tentang Pembungaan dan Pembentukan Buah Cokelat. Menara Perkebunan 45 (2):95100.

, dan Satifah. 1984. Pengetahuan Dasar dan Biologi Bunga dan Teknik Penyerbukan Silang Buatan. Penerbit PT. Gramedia, Jakarta. $156 \mathrm{~h}$.

Dwijoseputro. 1981. Pengantar Fisiologi Tumbuhan. PT. Gramedia. Jakarta. $200 \mathrm{~h}$.

El Zeftawi, B.M. 1980. Regulating pe Harvest Fruit Drop Andduration of the Harvest Season of Grape Fruit With 2,4 D and GA. Harc.Sci. 55(3):211-217.

Epstein, E. 1972. Mineral Nutrition of Plant. Principles and Perspectives. John Willey and Sons. Inc. USA. $412 \mathrm{p}$.

Isbandi, D. 1983. Pertumbuhan dan Perkembangan Tanaman. Jurusan Budidaya Pertanian. Fakultas Pertanian UGM Yogyakarta. 259 h.

Leopold, A.C. and P.E. Kriedeman. 1975. Plant Growth and Development (second ed). Tata Mc. Graw-Hill Book Co.Inc New York. $545 \mathrm{p}$.

Marschner, H. 1986. Mineral Nutrition in higher Plants. Academic Press Inc. London 545 p.

Mengel, K. and E.A. Kirkby. 1979. Principles of Plant Nutrition. International Potash Institute. Bern Switzerland. 593 p. 
Prawiranata, S., dan Haran P. Tjondronegoro. 1971. Dasar-dasar Fisiologi Tumbuhan. Departemen Botani Fakultas Pertanian IPB.

Soediyanto. 1976. Pedoman Bercocok Tanam Cokelat. Direktorat Jenderal Perkebunan. Departemen Pertanian Jakarta. $161 \mathrm{~h}$.

Soenaryo. 1978. Budidaya dan Pengolahan Cokelat. Balai Penelitian Perkebunan Bogor. Bogor. $53 \mathrm{~h}$.

Susanto, F.X. 1994. Tanaman Kakao Budidaya dan Pengolahan Hasil. Penerbit Kanisius Yogyakarta. $183 \mathrm{~h}$.
Suwartini, S. 1990. Pengaruh Pemberian Pupuk Daun dan Zat Pengatur Tumbuh Terhadap Pertumbuhan Buah dan Hasil Kakao. $91 \mathrm{~h}$.

Weaver, R.J. 1972. Plant Growth Substance in Agriculture. W.H. Freeman and Co San Fransisco. 594 p.

Wood, G.A.R. 1975. Cacao (third edition). Longman, London and New York. $292 \mathrm{p}$.

Zaenal. 1987. Dasar-dasar Pengetahuan Tentang Zat Pengatur Tumbuh. Penerbit Angkasa Bandung. $85 \mathrm{~h}$. 
